Mongolian Geoscientist

Original Article

\title{
Multi-stage serpentinization of ultramafic rocks in the Manlay Ophiolite, southern Mongolia
}

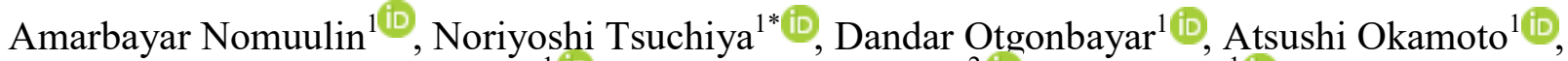 \\ Masaoki Uno ${ }^{1(\mathbb{D})}$, Batsaikhan Undarmaa ${ }^{2}$ (i) Jiajie Wang ${ }^{1(\mathbb{D})}$ \\ ${ }^{1}$ Graduate School of Environmental Studies, Tohoku University, Aoba 6-6-20, Aramaki Aoba-ku, Sendai 980-8579, Japan \\ ${ }^{2}$ School of Geology and Mining, Mongolian University of Science and Technology, Ulaanbaatar 14191, Mongolia \\ *Corresponding author: noriyoshi.tsuchiya.e6@tohoku.ac.jp, ORCID: 0000-0001-8176-6849
}

\section{ARTICLE INFO}

Article history:

Received 1 September, 2021

Accepted 25 December, 2021

\begin{abstract}
Serpentinization of ultramafic rocks in ophiolites is key to understanding the global cycle of elements and changes in the physical properties of lithospheric mantle. Mongolia, a central part of the Central Asian Orogenic Belt (CAOB), contains numerous ophiolite complexes, but the metamorphism of ultramafic rocks in these ophiolites has been little studied. Here we present the results of our study of the serpentinization of an ultramafic body in the Manlay Ophiolite, southern Mongolia. The ultramafic rocks were completely serpentinized, and no relics of olivine or orthopyroxene were found. The composition of $\mathrm{Cr}$-spinels $\left[\mathrm{Mg} \#=\mathrm{Mg} /\left(\mathrm{Mg}+\mathrm{Fe}^{2+}\right)\right.$ $=0.54$ and $\mathrm{Cr} \#=\mathrm{Cr} /(\mathrm{Cr}+\mathrm{Al})=0.56]$ and the bulk rock chemistry $(\mathrm{Mg} / \mathrm{Si}=1.21-$ 1.24 and $\mathrm{Al} / \mathrm{Si}<0.018$ ) of the serpentinites indicate their origin from a fore-arc setting. Lizardite occurs in the cores and rims of mesh texture $(\mathrm{Mg \#}=0.97)$ and chrysotile is found in various occurrences, including in bastite $(\mathrm{Mg} \#=0.95)$, mesh cores $(\mathrm{Mg} \#=0.92)$, mesh rims $(\mathrm{Mg} \#=0.96)$, and later-stage large veins $(\mathrm{Mg \#}=$ 0.94). The presence of lizardite and chrysotile and the absence of antigorite suggests low-temperature serpentinization $\left(<300^{\circ} \mathrm{C}\right)$. The lack of brucite in the serpentinites implies infiltration of the ultramafic rocks of the Manlay Ophiolite by Si-rich fluids. Based on microtextures and mineral chemistry, the serpentinization of the ultramafic rocks in the Manlay Ophiolite took place in three stages: (1) replacement of olivine by lizardite, (2) chrysotile formation (bastite) after orthopyroxene and as a replacement of relics of olivine, and (3) the development of veins of chrysotile that cut across all previous textures. The complex texture of the serpentinites in the Manlay Ophiolite indicates multiple stages of fluid infiltration into the ultramafic parts of these ophiolites in southern Mongolia and the CAOB.
\end{abstract}

Keywords: Manlay Ophiolite, multi-stage serpentinization, southern Mongolia, serpentinite

\section{INTRODUCTION}

Serpentinization is the formation of serpentine group minerals as a result of the hydrothermal alteration of $\mathrm{Mg}$-rich minerals such as olivine, orthopyroxene, and clinopyroxene in ultramafic rocks (Pinti, 2011). Serpentine is an important group of hydrous minerals that contain up to $13 \% \mathrm{H}_{2} \mathrm{O}$ (e.g., Hattori and Guillot, 2007), and the three important polymorphs (lizardite, chrysotile, and antigorite) may form variously in response to a variety of temperatures and geological settings (Evans et al., 2013).

(C) The Author(s). 2021 Open access This article is distributed under the terms of the Creative Commons Attribution 4.0 International License (https://creativecommons.org/licenses/by/4.0/), which permits unrestricted use, distribution, and reproduction in any medium, provided you give appropriate credit to the original author(s) and source, provide a link to the Creative Commons license, and indicate if changes were made 
Serpentinization commonly proceeds at slow to ultraslow spreading ridges, in mantle wedges (Hattori and Guillot, 2007; Deschamps et al., 2013), and along strike-slip faults (Guillot and Hattori, 2013; Uno and Kirby, 2019). In terms of the stability of serpentine minerals, lizardite is stable at temperatures below $300{ }^{\circ} \mathrm{C}$, the transition from lizardite to antigorite starts at around $300{ }^{\circ} \mathrm{C}$, and chrysotile is considered metastable at any temperature (e.g., Moody, 1976; Deschamps et al., 2013; Evans et al., 2013). The precipitation of magnetite, brucite, and talc that often accompanies serpentinization provides information on the temperatures, water -rock ratios, and chemistry of interacting fluids during the serpentinization process (e.g., Bach et al., 2004; Frost and Beard 2007; Klein et al., 2014; Schwarzenbach et al., 2016; Oyanagi et al., 2020).

Serpentinization plays a significant role in the global circulation of water and the geochemical cycles of subduction zones. Serpentine minerals incorporate water and fluid-mobile elements into their structures; therefore, they play an effective role in the transport of elements from slabs to mantle wedges and from mantle wedges to arc magmas (Hattori and Guillot, 2007). The buoyant property of serpentinite enables it to facilitate the exhumation of ultrahigh- and highpressure metamorphic rocks to the surface, and its rheology and dehydration cause deep seismic activity in subduction zones (e.g., Schwartz et al., 2001; Dobson et al., 2002; Hattori and Guillot, 2007). The serpentinization of ultramafic rocks is accompanied by the production of hydrogen, which can contribute to sustainable development by generating clean energy and sustaining ecosystems on the deep seafloor (e.g., Martin et al., 2008; Ohara et al., 2012; Wang et al., 2019). Furthermore, partially serpentinized ultramafic rocks and serpentinites are highly reactive to carbonation processes and have a high capacity for sequestering anthropogenic carbon dioxide emissions (e.g., Power et al., 2013; Wang et al., 2019). The ultramafic rocks of ophiolites preserve crucial information on the processes of serpentinization and carbonation.

The Central Asian Orogenic Belt (CAOB), also known as the Altaids (Şengőr et al., 1993), is one of the best-preserved and largest orogenic belts. The belt is surrounded by the Siberian, North China, and Tarim cratons, and it extends from the Urals in the west through Kazakhstan, NW China, Mongolia, and NE China to the Okhotsk Sea in East Russia (Jahn et al., 2004). The CAOB records the opening and closure of the Paleo-Asian Ocean from the Neoproterozoic to the Paleozoic (Blight, 2010), but its tectonic evolution remains controversial. Şengőr et al. (1993) suggested that it formed by the crustal growth of subduction-accretionary complexes along a single magmatic arc. In contrast, Badarch et al. (2002) and Windley et al. (2007) suggested that it is an accretionary-type orogenic belt that formed by the amalgamation of fragments of island arcs, ophiolite complexes, seamounts, accretionary wedges, and microcontinents.

The CAOB is considered an important area for studying juvenile crustal growth. Furthermore, the belt contains numerous Neoproterozoic to Triassic ophiolite complexes, which can provide vital information on (1) how the orogenic belt originated in the place of a former ocean (Furnes and Safonova, 2019) and (2) how hydration (serpentinization) and/or carbonation processes took place during the evolution of the belt (Dandar et al., 2019; Dandar et al., 2021). However, the metamorphism and hydrothermal alteration of ophiolites in the CAOB have not been studied sufficiently, except for the Khantaishir Ophiolite (Dandar et al., 2019; Dandar et al., 2021).

In this paper, we present our results from a study of the completely serpentinized ultramafic rocks of the Manlay Ophiolite, which is one of the best -preserved and most significant ophiolites in southern Mongolia and the CAOB. We first present details of the microstructures and mineral chemistry of the ultramafic rocks. We then discuss plausible conditions for the serpentinization, the multiple stages of serpentinization, and how our results contribute to an understanding of the alteration of ultramafic rocks in the ophiolites of southern Mongolia and the CAOB.

\section{GEOLOGICAL SETTINGS}

In terms of its geology, Mongolia can be 

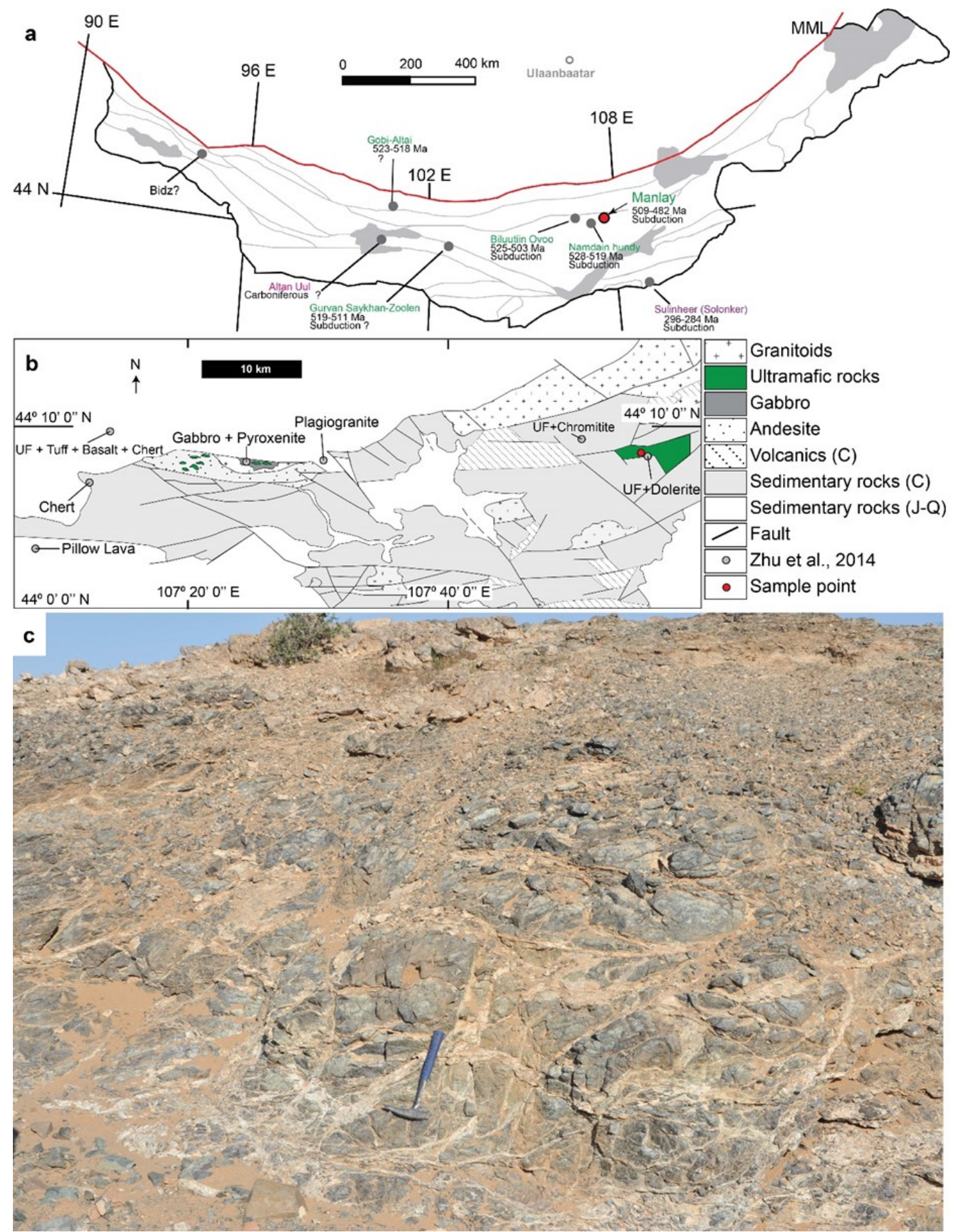

Fig. 1. Location of the Manlay Ophiolite. (a) Simplified terrane map of southern Mongolia and ophiolite distribution in southern Mongolia (modified from Badarch et al., 2002; Furnes and Safonova, 2019). Ophiolites are shown with ages and tectonic setting. Question marks indicate uncertain ages or tectonic setting. The gray open circle indicates the location of the city of Ulaanbatar. Gray circles indicate localities of ophiolite in southern Mongolia. The red circle shows the location of the Manlay Ophiolite. The red line is the Main Mongolian Lineament (MML). C, J and Q indicate Carboniferous, Jurassic and Quaternary, respectively (b) Simplified geological map of the eastern side of the Manlay Ophiolite (modified from Zhu et al., 2014a). (c) Field photo of serpentinite in the Manlay Ophiolite. Carbonate veins cut across the serpentinite massif. 
subdivided into northern and southern domains that are separated by the Main Mongolian Lineament (Fig. 1a). According to Badarch et al. (2002), the northern domain consists mainly of Precambrian and lower Paleozoic metamorphic rocks, Neoproterozoic ophiolite complexes, late Paleozoic island-arc, volcanic, and volcaniclastic rocks, Devonian to Carboniferous sediments, Permian volcanic-plutonic belts and marine and non-marine sediments, and granitoids of various ages.

The southern domain consists mainly of island arc terranes, back-arc and fore-arc basins, and cratonic blocks. It contains an abundance of lower to middle Paleozoic arc-related volcanic and volcaniclastic rocks with fragments of ophiolite and serpentinite melange. In the western part of the domain, Lower Devonian to middle Carboniferous carbonate, siliciclastic, and volcanic rocks are distributed (Lamb and Badarch, 1997). In the eastern part, Silurian and Devonian fossil-rich limestones, terrigenous, and volcaniclastic rocks, Carboniferous to Permian volcanic rocks, Permian limestones, and turbidites occur. In addition, Mesozoic granite plutons are exposed and overlapped by Upper Jurassic to Cretaceous non-marine volcanic and sedimentary rocks (Badarch et al., 2002)

South Mongolia has become a crucial area for mineral exploration, and there has been much research into subduction-related porphyry copper deposits such as the Late Devonian Oyu Tolgoi and Tsagaan Suvarga and the Carboniferous Shuteen and Kharmagtai deposits (Lamb and Cox, 1998; Perello et al., 2001) as well as research into the relationships of various mineral deposits and granitoids (Blight, 2010). Nevertheless, there is a general lack of geochemical and geochronological data on many of the dismembered ophiolites that are distributed in south Mongolia.

Our study was focused on the Manlay ophiolite complex of Cambrian age, which has suprasubduction signatures, and which is thought to be the basement of late Paleozoic arc formations and correlate with the Lake Zone in western Mongolia. The ophiolite is located on the border of the Gurvansayhan and Mandalovoo islandarc terranes in southern Mongolia (Fig. 1a; Zhu et al., 2014a). The Gurvansayhan Terrane is interpreted to be the result of island arc accretion and rifting (Batkhishig et al., 2010), and consists of dismembered ophiolite and melange, Ordovician to Silurian greenschistfacies metamorphosed sandstones, argillites, cherts, and volcaniclastic rocks, upper Silurian to Lower Devonian radiolarian cherts, tholeiitic pillow basalts, andesites, and tuffs, and Middle Devonian to early Carboniferous volcaniclastic rocks, cherts, and minor olistostromes with coral limestone clasts. The terrane was intruded by Permian granitoids, and overlapped by Carboniferous, Permian, Jurassic, and Cretaceous volcanic and sedimentary rocks (Badarch et al., 2002). The central and northern parts of the terrane contain serpentinite bodies and highly deformed metamorphosed siliciclastic sequences (Lamb and Badarch, 1997). In comparison, the Mandalovoo Terrane is a long narrow belt that consists of Ordovician and Silurian sandstones, argillites, and limestones; Lower Devonian conglomerates, sandstones, limestones, and felsic tuffs; Upper Devonian pillow basalts, andesites, volcaniclastic sandstones, and cherts; lower Carboniferous marine sedimentary rocks; and Devonian plutonic rocks (Badarch et al., 2002). The geochemical and geochronological characteristics of crustal rocks in the Manlay ophiolite complex show that the ophiolite is a basement of Devonian and early Carboniferous arc rocks that could be linked to the Lake Zone in western Mongolia (Zhu et al., 2014a). The Manlay ophiolitic complex consists mainly of ultramafic rocks, basalts, and cherts (Fig. 1b). The western part is characterized by basalts with minor chert, ultramafic rocks, plagiogranites, gabbros, and pyroxenites, the eastern part is dominated by carbonated ultramafic rocks, intrusions of dolerite, and thin chromitite veins, the southeastern part exposes pillow lavas, and the northwestern part contains andesites and tuffaceous sandstones interlayered with siliceous shale. The plagiogranites and gabbros yield U$\mathrm{Pb}$ ages of 482-509 Ma. Whole-rock geochemical data indicate that the origin of the Manlay Ophiolite was a supra-subduction zone, because the basalt and diabase samples are enriched in large-ion lithophile elements 
(LILEs; $\mathrm{Rb}, \mathrm{Sr}, \mathrm{Pb}$ and $\mathrm{K}$ ) and light rare-earth elements (LREEs; La, Ce, Pr, Nd, and Sm) with moderate to strong negative $\mathrm{Nb}, \mathrm{Ta}$, and $\mathrm{Ti}$ and weak $\mathrm{Eu}$ anomalies. The ultramafic rocks have very high loss on ignition (LOI) values that correspond to the extensive serpentinization and carbonation (Zhu et al., 2014a).

\section{Samples and analytical techniques}

The analyzed serpentinized ultramafic rocks from the Manlay Ophiolite (Fig. 1b [N44 ${ }^{\circ}$ 08'44"; E107'54'56"] and Table 1) are massive and show dark gray to brownish colors (Fig. 1c). In outcrop, the serpentinites are cut by white to brownish carbonate veins (Fig. 1c). The mineral assemblages and microtextures were observed in thin sections with an Olympus BX51 microscope equipped with an Olympus DP21 camera at Tohoku University, Japan.

Raman spectroscopy was performed with a Horiba XploRa Raman spectrometer and Olympus BX51 microscope at Tohoku University to distinguish the minerals of the serpentine group (lizardite, chrysotile, and antigorite). The calibrations were performed using synthetic silicon and the $520 \mathrm{~cm}^{-1}$ band. The estimated spectral resolution was $1.0 \mathrm{~cm}^{-1}$. We used a grating of $1800 \mathrm{~g} / \mathrm{mm}$, a x100 objective, a $1 \mu \mathrm{m}$ laser spot size, and a green laser with a wavelength of $532 \mathrm{~nm}$, and the integration time was $5 \mathrm{~s}$. The serpentine minerals were identified using information from Auzende et al. (2004) and Schwartz et al. (2013), and spectral regions were from 200 to $1200 \mathrm{~cm}^{-1}$ for lower wavelengths and from 3600 to $3800 \mathrm{~cm}^{-1}$ for higher wavelengths (Fig. 2). The Raman spectra of each mineral have been double-checked against the RRUFF Raman database.

The chemical compositions of the minerals were determined using an electron probe microanalyzer (EPMA; JEOL JXA-8200) at Tohoku University. The natural and synthetic standards used for calibration were wollastonite for $\mathrm{Ca}$ and $\mathrm{Si}$, rutile for $\mathrm{Ti}$, eskolaite for $\mathrm{Cr}$, hematite for $\mathrm{Fe}$, manganosite for $\mathrm{Mn}$, periclase for $\mathrm{Mg}$, albite for $\mathrm{Na}$, and $\mathrm{K}$-feldspar for $\mathrm{K}$. The accelerating voltage and beam currents were set at $15 \mathrm{kV}$ and $12 \mathrm{nA}$ for the quantitative analyses. The focused beam diameter was 1-2 $\mu \mathrm{m}$. The counting times for the peaks and backgrounds were 10 and $5 \mathrm{~s}$, respectively. Elemental mappings were performed in order to understand the distribution and correlations of elements. The accelerating voltage and beam currents were set at $15 \mathrm{kV}$ and $120 \mathrm{nA}$ for mapping, and the dwell time was $30 \mathrm{~s}$ per pixel. The concentrations of major elements $\left(\mathrm{SiO}_{2}\right.$, $\mathrm{TiO}_{2}, \mathrm{Al}_{2} \mathrm{O}_{3}, \mathrm{Fe}_{3} \mathrm{O}_{2}, \mathrm{MnO}, \mathrm{MgO}, \mathrm{CaO}, \mathrm{Na}_{2} \mathrm{O}$, $\mathrm{K}_{2} \mathrm{O}$, and $\mathrm{P}_{2} \mathrm{O}_{5}$ ) were determined using wavelength dispersive $\mathrm{X}$-ray fluorescence spectrometry (WDXRF; Rigaku ZSX Primus IV) with relative mean square error (RMSE) ranging from $0.77 \%$ for $\mathrm{SiO}_{2}$ to $0.003 \%$ for $\mathrm{MnO}$ and correlation coefficient (R) of the linear regression lines of $>0.99$, whereas the minor and some trace elements $(\mathrm{V}, \mathrm{Cr}, \mathrm{Co}, \mathrm{Ni}, \mathrm{Cu}, \mathrm{Zn}, \mathrm{Rb}$, $\mathrm{Sr}, \mathrm{Y}, \mathrm{Zr}, \mathrm{Nb}, \mathrm{Sn}, \mathrm{Cs}, \mathrm{Ba}, \mathrm{La}, \mathrm{Ce}, \mathrm{Pr}, \mathrm{Nd}, \mathrm{Pb}$, and $\mathrm{Th}$ ) were measured using energy dispersive X-ray fluorescence spectrometry (EDXRF; PANalytical Epsilon 5; Table 2) with RMSE of $<28 \mathrm{ppm}$ and $\mathrm{R}$ of $>0.96$, except for Co with $\mathrm{R}$ $=0.89$ and Pr with $\mathrm{R}=0.84$. In terms of sample preparation, $\sim 100 \mathrm{~g}$ of each rock sample was

Table 1. Mineral assemblages of samples collected from the Manlay Ophiolite. $\mathrm{Ol}=$ Olivine, $\mathrm{Opx}=$ Orthopyroxene, $\mathrm{Spl}=$ Spinel, $\mathrm{Cpx}=$ Clinopyroxene, $\mathrm{Ser}=$ Serpentine, Mgt = Magnetite, $\mathrm{Cal}=$ Calcite .

\begin{tabular}{|c|c|c|c|c|c|c|c|}
\hline \multirow{2}{*}{ Sample no. } & \multirow{2}{*}{ Lithology } & \multicolumn{3}{|c|}{ Primary } & \multicolumn{3}{|c|}{ Secondary } \\
\hline & & $\mathrm{Ol} / \mathrm{Opx}$ & Spl & Cpx & Ser & Mgt & $\mathrm{Cal}$ \\
\hline 1809130201 & Serpentinite & & + & & + & + & + \\
\hline 1809130202 & Serpentinite & & + & & + & + & + \\
\hline 1809130203 & Serpentinite & & + & & + & + & + \\
\hline 1809130204 & Serpentinite & & + & & + & + & + \\
\hline 1809130205 & Serpentinite & & + & & + & + & + \\
\hline
\end{tabular}




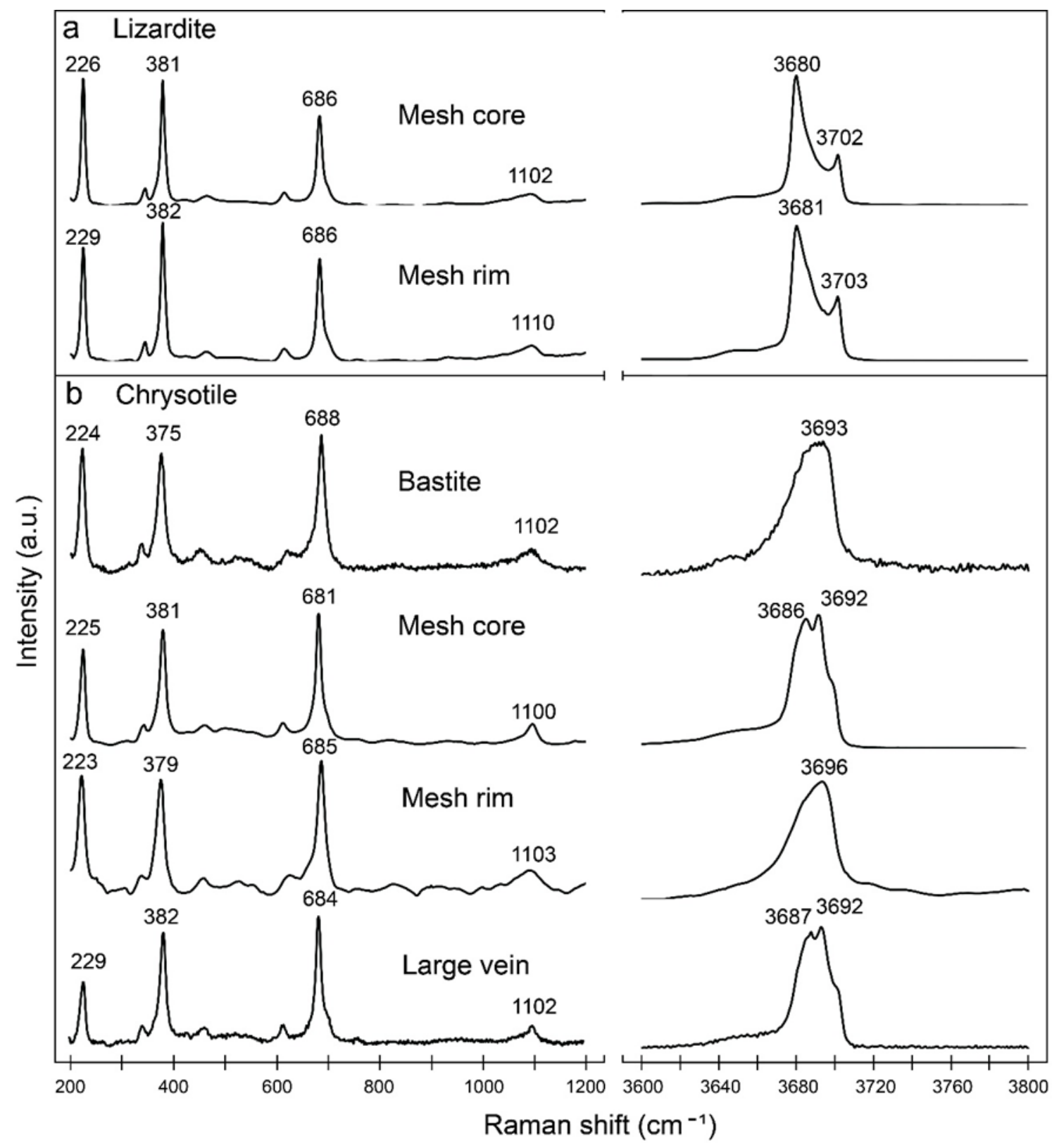

Fig. 2. Representative Raman spectra of the serpentine minerals. (a) Lizardite (mesh texture core and rim). (b) Chrysotile (bastite, mesh texture core, vein in mesh texture, and large vein).

crushed and milled to get a homogeneous powder. In order to eliminate moisture, 6 grams of powder from each sample were dried for $2 \mathrm{~h}$ at $105{ }^{\circ} \mathrm{C}$. The LOI values were determined after each sample had been heated at $950{ }^{\circ} \mathrm{C}$ in an electric furnace for 2 hours. The fusion glass bead method was used for the determination of major elements. Each glass bead was made from a mix of $5.4 \mathrm{~g}$ of lithium borate flux $\left(\mathrm{LiBO}_{2}=\right.$ $49.5 \%, \mathrm{Li}_{2} \mathrm{~B}_{4}=49.5 \%$, and $\mathrm{LiBr}=0.5 \%$ ) and $0.6 \mathrm{~g}$ of powder sample that was then fused at
$1150{ }^{\circ} \mathrm{C}$. The glass beads were exposed to Xrays using WDXRF (Rigaku ZSX Primus IV) and $\mathrm{a} \mathrm{Rh}$ anode tube with an acceleration voltage of $75 \mathrm{~kW}$ and a beam current of $8 \mathrm{~mA}$. Polyvinyl chloride (PVC) rings filled with homogenous powder from each sample were subjected to pressures of $150 \mathrm{kNPa}$ and 200 $\mathrm{kNPa}$ for $5 \mathrm{~min}$, respectively, to make the pressed powder pellets used for estimating the concentrations of minor and trace elements. To measure $\mathrm{V}, \mathrm{Cr}, \mathrm{Co}, \mathrm{Ni}, \mathrm{Cu}$, and $\mathrm{Zn}$, the pellets 
were exposed to X-rays using EDXRF, a Sc/W anode tube, a $75 \mathrm{~kW}$ acceleration voltage, and an $8 \mathrm{~mA}$ beam current. A $100 \mathrm{~kW}$ acceleration voltage and $6 \mathrm{~mA}$ beam were used to measure $\mathrm{Rb}, \mathrm{Sr}, \mathrm{Y}, \mathrm{Zr}, \mathrm{Nb}, \mathrm{Sn}, \mathrm{Cs}, \mathrm{Ba}, \mathrm{La}, \mathrm{Ce}, \mathrm{Pr}, \mathrm{Nd}$, $\mathrm{Pb}$, and $\mathrm{Th}$. Standard samples provided by the Geological Survey of Japan (GSJ; JP-1) were also measured during the XRF analyses. The WDXRF and EDXRF instruments was calibrated using 26 geological and environmental standard reference materials obtained from GSJ (Yamasaki et al., 2011).

\section{Microtextures of the serpentinites}

Serpentinites in the Manlay Ophiolite are made up dominantly of chrysotile and lizardite along with minor magnetite, calcite, and $\mathrm{Cr}$-spinel (Table 1). The primary olivines and orthopyroxenes of the original ultramafic rocks are completely gone from all the serpentinite samples. The low wavenumber Raman spectra peaks (124-126, 225-226, 379-380, and 1099. $1100 \mathrm{~cm}^{-1}$ ) and the high wavenumber peaks (3680-3681 and $3701 \mathrm{~cm}^{-1}$ ) indicate lizardite (Fig. 2a). The peaks at low wavenumbers (126$127,225-230,381-385,685-690$, and 1100 $\mathrm{cm}^{-1}$ ) are similar to those of lizardite, but a single high wavenumber peak (3692-3694 $\mathrm{cm}^{-1}$ ) indicates chrysotile (Fig. 2a and b). Chrysotile occurs commonly as a bastite texture (orthopyroxene pseudomorphs) and in large veins, and small amounts also occur in mesh texture cores and rims. In contrast, lizardite occurs only as mesh texture (Fig. 3a-e). Mesh cores and large veins show three high wavenumber peaks (3686-3687, 3692, and 3699 $-3700 \mathrm{~cm}^{-1}$ ) indicating a mixture of chrysotile and lizardite at the microscopic level (less than the size of the beam spot of the micro-Raman spectroscope; Fig. 2b). We refer to this mixture of lizardite and chrysotile in mesh cores and large veins as chrysotile because (1) the Al and Fe contents of the chrysotile mesh cores are similar to the $\mathrm{Al}$ and $\mathrm{Fe}$ contents of the chrysotile in bastite textures and mesh rims, and (2) the chrysotile large veins are crack-filling veins in which lizardite particles could be included (Fig. 3). If chrysotile occurs in the mesh rims and bastite textures, it is colorless, but the large veins have a yellowish color (Fig.
Table 2. Bulk-rock major and minor element compositions of selected ultramafic rocks from the Manlay Ophiolite.

\begin{tabular}{|c|c|c|c|}
\hline \multirow{2}{*}{$\begin{array}{l}\text { Locality } \\
\text { Sample }\end{array}$} & \multicolumn{3}{|c|}{ Manlay ophiolite } \\
\hline & Serpentinite & Serpentinite & Serpentinite \\
\hline$\overline{~ № ~}$ & 1809130203 & 1809130204 & 1809130205 \\
\hline \multicolumn{4}{|c|}{ Major and minor elements $(X R F, w t \%)$} \\
\hline $\mathrm{SiO}_{2}$ & 45.2 & 44.6 & 44.5 \\
\hline $\mathrm{TiO}_{2}$ & $<0.02$ & $<0.02$ & $<0.02$ \\
\hline $\mathrm{Al}_{2} \mathrm{O}_{3}$ & 0.59 & 0.99 & 0.72 \\
\hline $\mathrm{Fe}_{2} \mathrm{O}_{3}$ & 7.98 & 7.84 & 9.12 \\
\hline $\mathrm{MnO}$ & 0.08 & 0.11 & 0.15 \\
\hline $\mathrm{MgO}$ & 43.5 & 42.9 & 42.0 \\
\hline $\mathrm{CaO}$ & 0.67 & 1.25 & 1.28 \\
\hline $\mathrm{Na}_{2} \mathrm{O}$ & $<0.03$ & $<0.03$ & $<0.03$ \\
\hline $\mathrm{K}_{2} \mathrm{O}$ & $<0.05$ & $<0.05$ & $<0.05$ \\
\hline $\mathrm{P}_{2} \mathrm{O}_{5}$ & 0.008 & 0.01 & 0.01 \\
\hline Total & 98.04 & 97.72 & 97.84 \\
\hline LOI & 14.5 & 14.6 & 15.1 \\
\hline \multicolumn{4}{|c|}{$w t \%$ ratio } \\
\hline $\mathrm{Mg} / \mathrm{Si}$ & 1.245 & 1.240 & 1.219 \\
\hline $\mathrm{Al} / \mathrm{Si}$ & 0.015 & 0.002 & 0.018 \\
\hline \multicolumn{4}{|c|}{$X R F(p p m)$} \\
\hline V & 13.96 & 20.46 & 17.98 \\
\hline $\mathrm{Cr}$ & 2665 & 3511 & 3098 \\
\hline $\mathrm{Ni}$ & 2745 & 2910 & 3006 \\
\hline $\mathrm{Rb}$ & $<0.4$ & 0.46 & $<0.4$ \\
\hline $\mathrm{Sr}$ & 26.25 & 32.84 & 41.46 \\
\hline $\mathrm{Ba}$ & 14.91 & 19.87 & 22.72 \\
\hline
\end{tabular}

3a-c). Moreover, lizardite is colorless, but if it occurs in the mesh cores, it takes on a brownish color (Fig. 3b). The grain size of the lizardite varies from 50 to $200 \mu \mathrm{m}$. The chrysotile grains in bastites are $\sim 10 \mu \mathrm{m}$ in size and size of the bastite varies from 125 to $2000 \mu \mathrm{m}$. Finegrained (mostly $<10 \mu \mathrm{m}$, rarely up to $100 \mu \mathrm{m}$ ) calcite occurs as veins and patchy textures that crosscut the serpentine minerals and are associated with fractures (Fig. 3b). In contrast, fine-grained $(10-100 \mu \mathrm{m})$ magnetite forms veins within the bastite that follow the former cleavages of the orthopyroxene (Fig. 3b-e), and it is also found inside mesh textures (Fig. 3e and d) and locally within calcite. Cr-spinel occurs as anhedral to subhedral crystals $100-2000 \mu \mathrm{m}$ in size (Fig. 3a, d, and e), and it is usually rimmed by magnetite. 

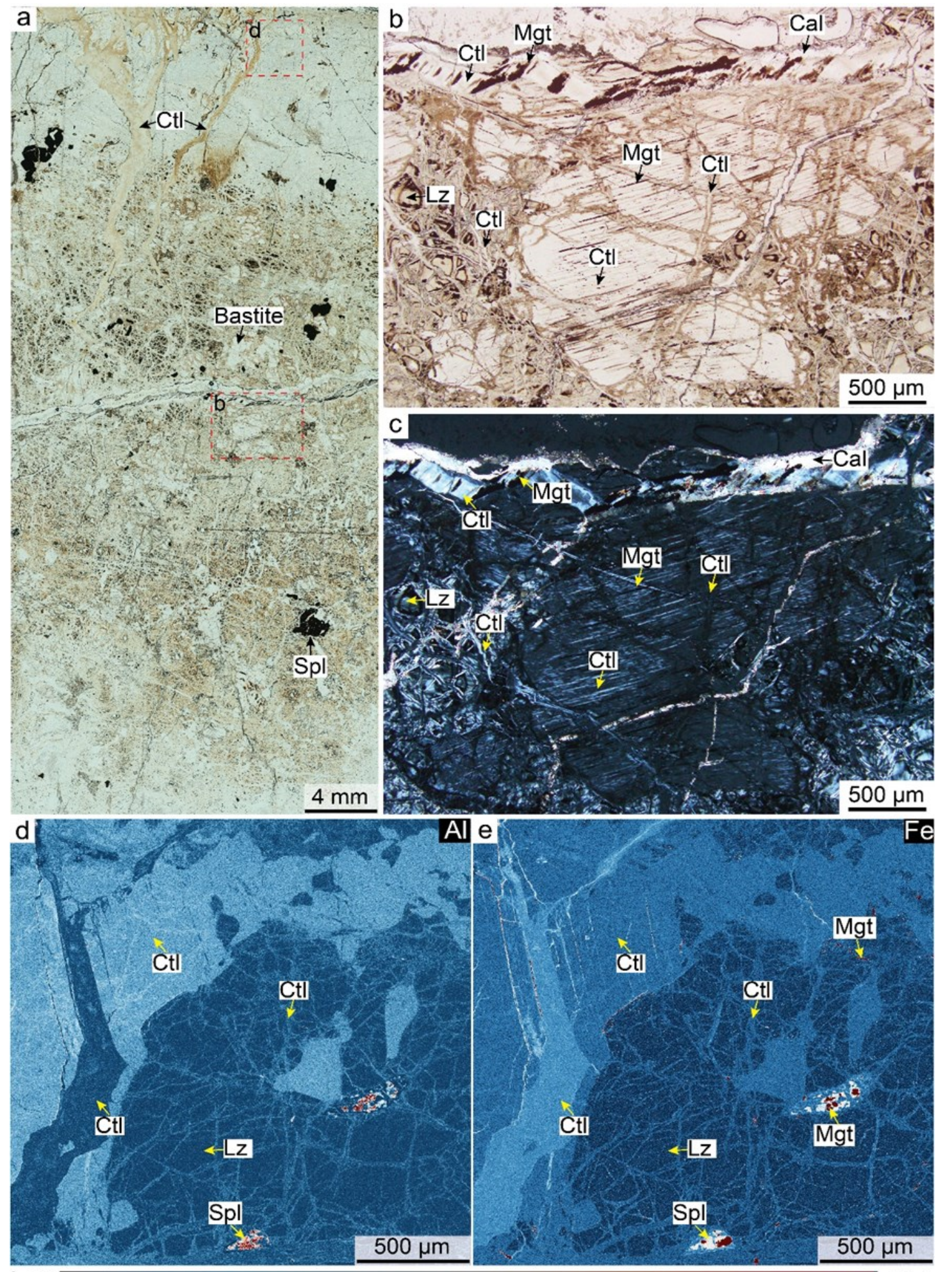

Low

High

Fig. 3. Microstructure of a representative serpentinite sample. (a) Photomicrograph of a representative sample under plane-polarized light. Red dashed rectangles indicate the areas shown in (b) and (d). (b) and (c) Bastite and vein chrysotile with mesh textured lizardite under plane-polarized light and cross-polarized light, respectively. (d) and (e) $\mathrm{Al}$ and Fe mappings, respectively. The large chrysotile vein, the chrysotile bastite, and the lizardite mesh texture core have different $\mathrm{Al}$ and $\mathrm{Fe}$ contents. $\mathrm{Ctl}=$ chrysotile; $\mathrm{Lz}=$ lizardite $; \mathrm{Mgt}=$ magnetite, $\mathrm{Spl}=$ spinel, $\mathrm{Cal}=$ calcite . 


\section{Mineral chemistry}

\section{Serpentine minerals}

The chrysotiles are rich in Fe with $\mathrm{Mg} \#(=\mathrm{Mg} /$ $\left.\mathrm{Mg}+\mathrm{Fe}_{\text {total }}\right)$ values varying slightly from bastite cores $(\mathrm{Mg \#}=0.96)$ to bastite rims $(0.95)$, mesh cores (0.92), mesh rims (0.96), and large veins (0.94), whereas the lizardites (mesh cores and rims) are relatively poor in $\mathrm{Fe}$ with nearly constant $\mathrm{Mg \#}$ values of 0.97 (Table 3). Chrysotiles in bastite cores and rims have elevated $\mathrm{Cr}_{2} \mathrm{O}_{3} \quad(0.23-0.55$ wt.\%) contents relative to the contents $(<0.05$ wt. $\%)$ of chrysotiles in mesh textures, large chrysotile veins, and mesh-textured lizardite (Fig. 4a). The
$\mathrm{Al}_{2} \mathrm{O}_{3}$ contents of bastite-textured chrysotiles are higher than those of mesh-textured chrysotiles (core $\mathrm{Al}_{2} \mathrm{O}_{3}=0.28-0.39$ wt. $\%$ and $\operatorname{rim~} \mathrm{Al}_{2} \mathrm{O}_{3}=$ 0.26-0.69 wt.\%), mesh-textured lizardites (core $\mathrm{Al}_{2} \mathrm{O}_{3}=0.16-0.39$ wt. $\%$ and $\operatorname{rim} \mathrm{Al}_{2} \mathrm{O}_{3}=0.37$ 0.54 wt.\%), and the chrysotiles in large veins $\left(\mathrm{Al}_{2} \mathrm{O}_{3}=0.2-0.41\right.$ wt.\%; Fig. $4 \mathrm{a}$ and b). The $\mathrm{FeO}$ contents (1.5-2.16 wt.\%) of mesh-textured lizardites are lower than those of chrysotiles in mesh rims (2.3-3.5 wt.\%), bastite-textured chrysotiles (core $\mathrm{FeO}=2.44-3.3$ wt. $\%$ and rim $\mathrm{FeO}=2.98-3.76 \mathrm{wt} . \%$ ), chrysotiles in large veins (3.65-4.31 wt.\%), and chrysotiles in mesh cores (4.92-5.86 wt.\%; Fig. 4b).

Table 3. Average electron microprobe data (in wt.\%) and calculated structural formulae (in a.p.f.u) for serpentine minerals, spinel, and calcite. $\mathrm{Lz}=$ Lizardite, $\mathrm{Ctl}=\mathrm{Chrysotile}, \mathrm{Spl}=$ Spinel, $\mathrm{Cal}=\mathrm{Calcite}$.

\begin{tabular}{|c|c|c|c|c|c|c|c|c|c|}
\hline \multirow{3}{*}{$\begin{array}{c}\text { Lithology } \\
\text { Mineral }\end{array}$} & \multicolumn{7}{|c|}{ Serpentinite } & \multirow{3}{*}{ Spl } & \multirow{3}{*}{ Cal } \\
\hline & \multicolumn{2}{|c|}{ Lizardite } & \multicolumn{5}{|c|}{ Chrysotile } & & \\
\hline & $\begin{array}{l}\text { Mesh } \\
\text { core }\end{array}$ & Mesh rim & $\begin{array}{c}\text { Bastite } \\
\text { core }\end{array}$ & $\begin{array}{l}\text { Bastite } \\
\text { rim }\end{array}$ & $\begin{array}{c}\text { Mesh } \\
\text { core }\end{array}$ & Mesh rim & Large vein & & \\
\hline $\mathrm{N}$ & 10 & 10 & 20 & 20 & 10 & 30 & 10 & 20 & 19 \\
\hline $\mathrm{SiO}_{2}$ & 42.56 & 42.71 & 43.40 & 42.40 & 42.55 & 42.67 & 42.12 & 0.02 & 0.01 \\
\hline $\mathrm{TiO}_{2}$ & 0.02 & 0.01 & 0.01 & 0.02 & 0.02 & 0.02 & 0.01 & 0.02 & 0.02 \\
\hline $\mathrm{Al}_{2} \mathrm{O}_{3}$ & 0.27 & 0.45 & 1.00 & 1.17 & 0.35 & 0.46 & 0.31 & 22.99 & 0.01 \\
\hline $\mathrm{Cr}_{2} \mathrm{O}_{3}$ & 0.00 & 0.02 & 0.42 & 0.51 & 0.01 & 0.01 & 0.02 & 44.41 & 0.01 \\
\hline $\mathrm{FeO}$ & 1.74 & 1.77 & 2.88 & 3.26 & 5.57 & 2.82 & 4.05 & 21.30 & 0.10 \\
\hline $\mathrm{MnO}$ & 0.01 & 0.03 & 0.05 & 0.10 & 0.15 & 0.04 & 0.09 & 0.28 & 0.03 \\
\hline $\mathrm{CaO}$ & 0.05 & 0.04 & 0.15 & 0.14 & 0.09 & 0.06 & 0.08 & 0.01 & 55.32 \\
\hline $\mathrm{MgO}$ & 39.44 & 39.40 & 36.50 & 35.89 & 36.43 & 38.60 & 37.42 & 11.67 & 0.45 \\
\hline $\mathrm{NiO}$ & 0.08 & 0.08 & 0.32 & 0.17 & 0.36 & 0.14 & 0.32 & 0.08 & 0.01 \\
\hline $\mathrm{Na}_{2} \mathrm{O}$ & 0.02 & 0.01 & 0.03 & 0.03 & 0.03 & 0.02 & 0.02 & 0.02 & 0.04 \\
\hline $\mathrm{K}_{2} \mathrm{O}$ & 0.01 & 0.00 & 0.01 & 0.01 & 0.00 & 0.00 & 0.01 & 0.00 & 0.00 \\
\hline Total & 84.19 & 84.52 & 84.78 & 83.69 & 85.57 & 84.86 & 84.45 & 100.8 & 56.00 \\
\hline Oxygen & 7 & 7 & 7 & 7 & 7 & 7 & 7 & 4 & 1 \\
\hline $\mathrm{Si}$ & 2.040 & 2.039 & 2.078 & 2.062 & 2.050 & 2.041 & 2.041 & 0.000 & 0.000 \\
\hline $\mathrm{Ti}$ & 0.001 & 0.000 & 0.000 & 0.001 & 0.001 & 0.001 & 0.000 & 0.000 & 0.000 \\
\hline $\mathrm{Al}$ & 0.015 & 0.025 & 0.056 & 0.067 & 0.020 & 0.026 & 0.018 & 0.830 & 0.000 \\
\hline $\mathrm{Cr}$ & 0.000 & 0.001 & 0.016 & 0.019 & 0.000 & 0.001 & 0.001 & 1.070 & 0.000 \\
\hline $\mathrm{Fe}^{3+}$ & & & & & & & & 0.090 & 0.000 \\
\hline $\mathrm{Fe}^{2+}$ & 0.070 & 0.071 & 0.115 & 0.133 & 0.225 & 0.113 & 0.164 & 0.450 & 0.003 \\
\hline $\mathrm{Mn}$ & 0.001 & 0.001 & 0.002 & 0.004 & 0.006 & 0.002 & 0.004 & 0.000 & 0.000 \\
\hline $\mathrm{Ca}$ & 0.002 & 0.002 & 0.008 & 0.007 & 0.005 & 0.003 & 0.004 & 0.000 & 1.969 \\
\hline $\mathrm{Mg}$ & 2.819 & 2.805 & 2.605 & 2.603 & 2.617 & 2.753 & 2.703 & 0.530 & 0.023 \\
\hline $\mathrm{Ni}$ & 0.003 & 0.003 & 0.012 & 0.006 & 0.014 & 0.005 & 0.012 & 0.000 & 0.000 \\
\hline $\mathrm{Na}$ & 0.001 & 0.001 & 0.003 & 0.003 & 0.003 & 0.002 & 0.002 & 0.000 & 0.000 \\
\hline $\mathrm{K}$ & 0.000 & 0.000 & 0.000 & 0.000 & 0.000 & 0.000 & 0.000 & 0.000 & 0.000 \\
\hline $\begin{array}{l}\mathrm{Mg} \# \\
\mathrm{Cr} \#\end{array}$ & 0.976 & 0.975 & 0.958 & 0.952 & 0.921 & 0.961 & 0.943 & $\begin{array}{l}0.539 \\
0.564\end{array}$ & 0.012 \\
\hline
\end{tabular}

$\mathrm{Mg} \#=\mathrm{Mg} /(\mathrm{Mg}+\mathrm{Fe}), \mathrm{Cr} \#=\mathrm{Cr} /(\mathrm{Cr}+\mathrm{Al}), \mathrm{N}=$ number of measurement 
The serpentine minerals have $\mathrm{Si}+\mathrm{Al}$ values of 2.0 to 2.2, and the $\mathrm{Fe}+\mathrm{Mg}$ values of 2.5-3.0 decrease linearly with increasing $\mathrm{Al}+\mathrm{Si}$ (Fig. $4 c)$.

\section{Other minerals}

Calcites in the serpentinites have $\mathrm{X}_{\mathrm{MgCO} 3}$ $\left[\mathrm{X}_{\mathrm{MgCO} 3}=\mathrm{Mg} /(\mathrm{Mg}+\mathrm{Fe}+\mathrm{Ca})\right]$ values of 0.001 to 0.027 . Magnetites have relatively low $\mathrm{FeO}_{\text {total }}$ (79.63-84.15 wt.\%) contents and slightly high $\mathrm{SiO}_{2}(0.63-0.84$ wt.\%) and $\mathrm{MnO}(1.82-3.72$ wt.\%) contents. Relics of $\mathrm{Cr}$-spinel in the serpentinites have $\mathrm{Cr} \#$ and $\mathrm{Mg} \#$ values that range from 0.51 to 0.59 and 0.50 to 0.59 , which correspond to the values found in fore-arc peridotites. In contrast, Zhu et al. (2014a) showed that the Cr-spinels in the chromitites of the Manlay Ophiolite had compositions that plotted in the boninite field (Fig. 4d).

\section{Bulk rock major element compositions}

The bulk rock compositions of three serpentinite samples from the Manlay Ophiolite are shown in Table 2. The $\mathrm{SiO}_{2}, \mathrm{MgO}$, and $\mathrm{FeO}$ contents of the serpentinites show ranges of 44.5-45.2, 42.043.5, and 7.84-9.12 wt.\%, respectively. The
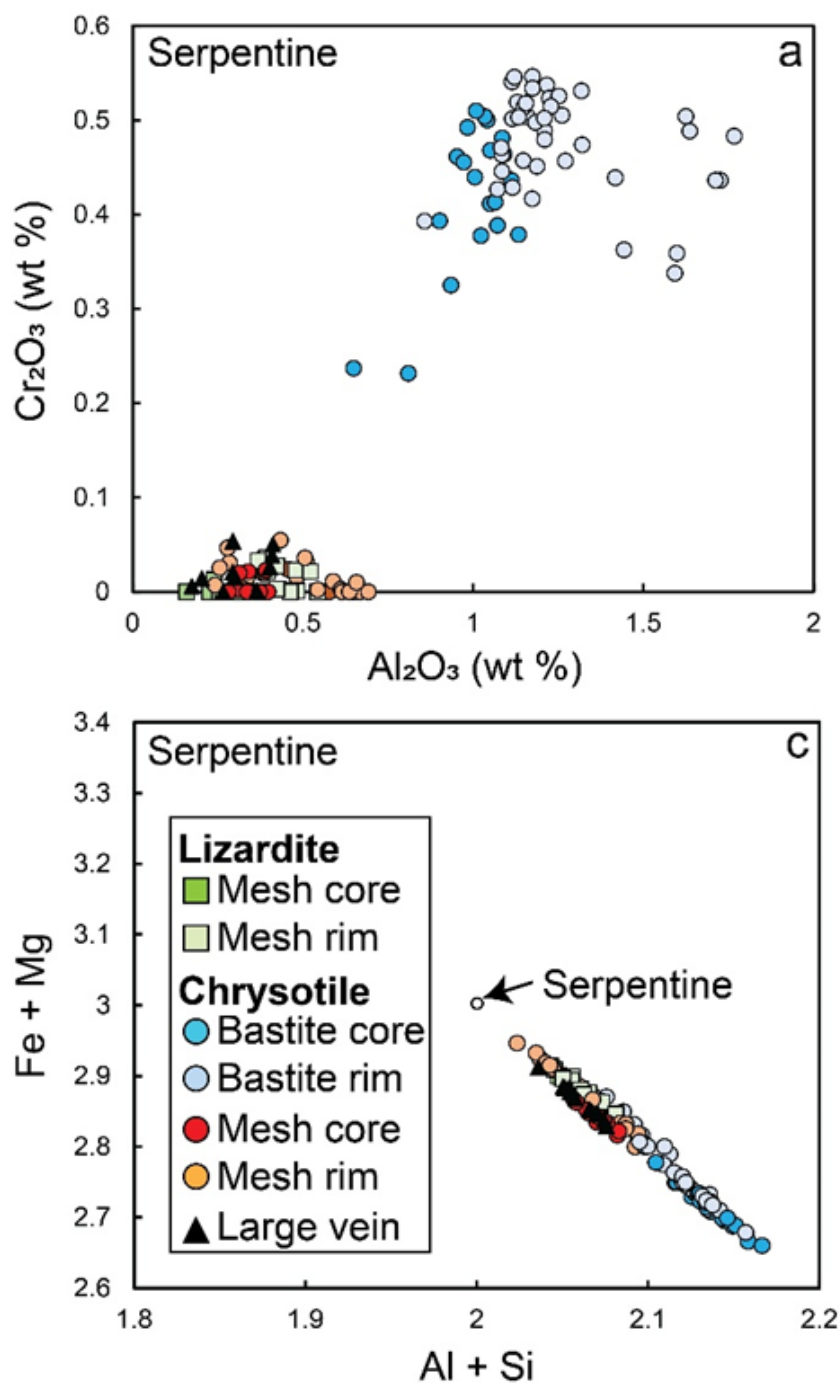
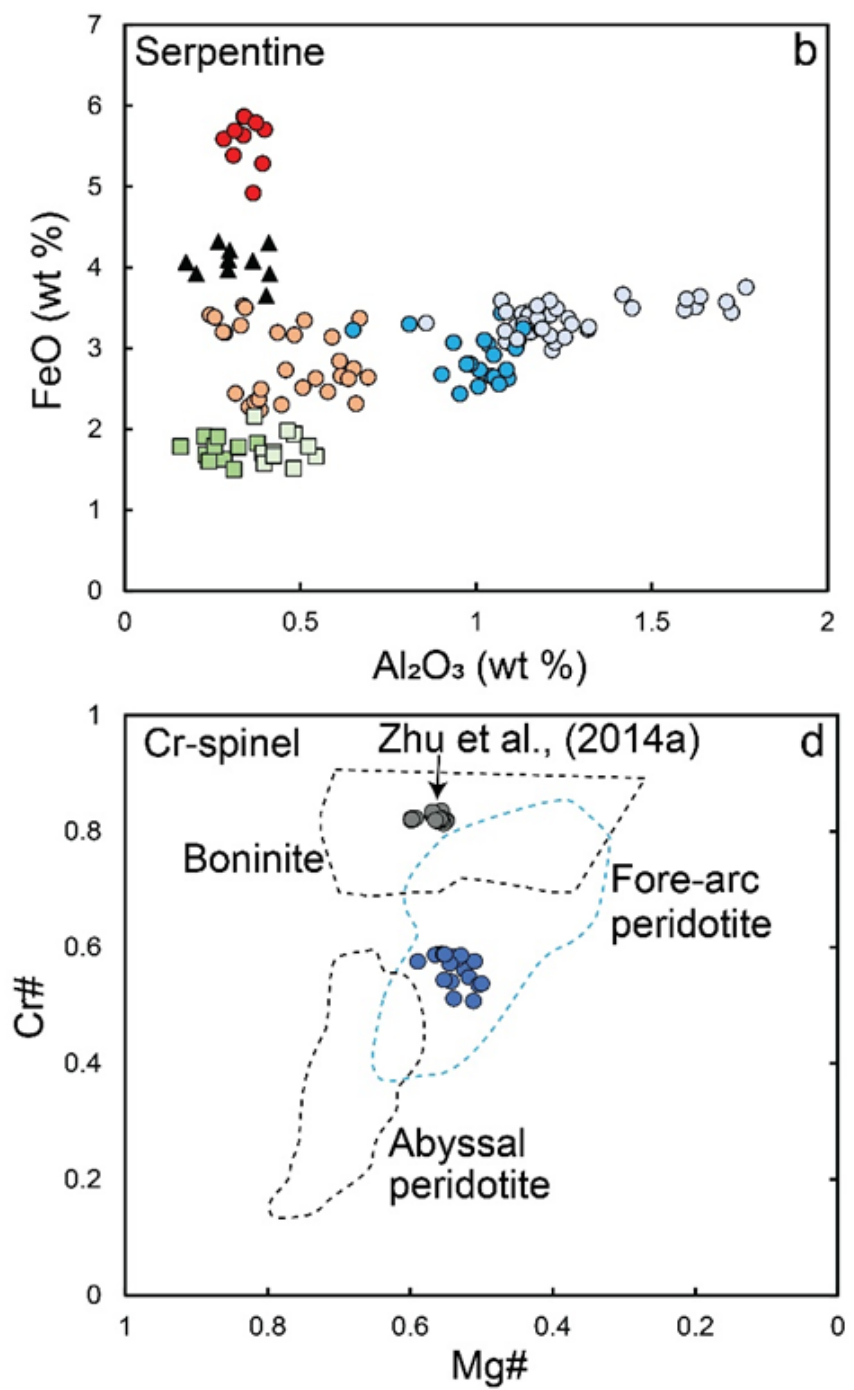

Fig. 4. Mineral chemistry. (a) Diagram comparing the $\mathrm{Cr}_{2} \mathrm{O}_{3}$ vs $\mathrm{Al}_{2} \mathrm{O}_{3}$ compositions of bastite and mesh textured serpentines. (b) Diagram comparing the $\mathrm{FeO}$ vs $\mathrm{Al}_{2} \mathrm{O}_{3}$ compositions of bastite and mesh textured serpentines. (c) Chemical compositions of serpentine minerals as a function of $\mathrm{Si}+\mathrm{Al}$ and $\mathrm{Mg}+\mathrm{Fe}$ cations per seven oxygens. Model serpentine $(\mathrm{Mg}=3$ and $\mathrm{Si}=2)$ is shown as the open circle. (d) Plot of $\mathrm{Mg \#}$ vs $\mathrm{Cr} \#$ for the chromian spinels in serpentinite (blue) and in chromitite (green, from Zhu et al., 2014). Areas of abyssal peridotite, fore-arc peridotite, and boninite are from Tamura and Arai (2006). 
$\mathrm{Al}_{2} \mathrm{O}_{3}$ and $\mathrm{CaO}$ contents exhibit ranges of 0.59 0.99 and 0.67-1.28 wt.\%, respectively. The LOI values vary from 14.5 to $15.1 \mathrm{wt} . \%$ (Table 2 ). The ratios of $\mathrm{Mg} / \mathrm{Si}$ in the serpentinites vary from 1.219-1.245 and the $\mathrm{Al} / \mathrm{Si}$ ratios are lower than 0.018 (Table 2).

\section{DISCUSSION}

\section{Plausible conditions of the serpentinization}

Primary minerals of the original ultramafic rocks, such as olivine and orthopyroxene, have not been observed in our serpentinite samples. The mesh serpentines are low in $\mathrm{Al}$ and $\mathrm{Cr}$, whereas the bastite serpentines are high in $\mathrm{Al}$ and $\mathrm{Cr}$ (Fig. 4a and b). The elemental mapping and thin section observations show that the bastite serpentines, which replaced orthopyroxene, occupy $\sim 12 \%$ of the serpentinite samples, which suggests that the ultramafic protolith was a harzburgite (Fig 3). The values of $\mathrm{Mg \#} \mathrm{(0.51-0.59)}$ and $\mathrm{Cr} \#(0.50-0.59)$ in the Cr-spinels of the serpentinites are similar, which indicates a fore-arc peridotite (Fig 4d).

In order to understand the serpentinization process, the various serpentine mineral species were identified. Lizardite and chrysotile are dominant in our samples and antigorite is absent, which suggests the serpentinization took place at temperatures below $300{ }^{\circ} \mathrm{C}$ (Deschamps et al., 2013; Fig 2), since many studies have emphasized that the transformation of lizardite to antigorite occurs at around $300-400{ }^{\circ} \mathrm{C}$ in a subduction zone setting (e.g., Deschamps et al., 2013, Lafay et al., 2013). The $\mathrm{Si}+\mathrm{Al}$ and $\mathrm{Mg}+$ Fe compositions of the serpentine minerals indicate that brucite is absent from our analyzed samples (Fig 4c). The (MgO-FeO)/SiO $\mathrm{S}_{2}$ ratios of the serpentinites are slightly lower than those of the original harzburgite (based on $\mathrm{Ol}=87$ vol. $\%$, Opx $=12$ vol. $\%$, spinel $=1$ vol. $\%$ ), which suggests that a Si-rich fluid infiltrated and reacted with the harzburgites (Fig 5) of the Manlay Ophiolite generating serpentines without brucite. The values of $\mathrm{Mg} / \mathrm{Si}$ and $\mathrm{Al} / \mathrm{Si}$ for the serpentinites in the Manlay Ophiolite are similar to those reported for the Mariana forearc (Table 2; Hattori and Guillot, 2007). Based on the identification of serpentine mineral species, mineral chemistry, and bulk rock compositions, we propose, therefore, that the ultramafic rocks of the Manlay Ophiolite interacted with silicarich fluids to become serpentinized at shallow levels of the mantle wedge (at temperatures lower than $300^{\circ} \mathrm{C}$ ).

\section{Multi-stage serpentinization}

The ultramafic rocks of the Cambrian Manlay Ophiolite may have been affected by several stages of serpentinization, and we identify three possible stages based on cross cutting relationships and mineral chemistry (Fig 6). First, compared with orthopyroxenes and clinopyroxenes, natural olivines tend to hydrate readily at low temperatures and pressures (e.g., Moody, 1976). The serpentinization of olivine produces mesh textures that develop during volume expansion ( $\sim 64 \%$; Holland and Powell, 1998) and hydration. In the Manlay Ophiolite, lizardite was found in the mesh textures, according to the results of Raman spectroscopic analysis (Fig 2). Consequently, we define Stage I of the serpentinization process as the formation of lizardite owing to the serpentinization of olivine, as shown in Eq. 1.

\section{$3 \mathrm{Mg}_{2} \mathrm{SiO}_{4}+4 \mathrm{H}_{2} \mathrm{O}+\mathrm{SiO}_{2}=2 \mathrm{Mg}_{3} \mathrm{Si}_{2} \mathrm{O}_{5}(\mathrm{OH})_{4}$ \\ Olivine Water Silica Lizardite}

The infiltration of Si-rich fluids into an ultramafic rock at low temperatures $\left(<300{ }^{\circ} \mathrm{C}\right)$ tends to inhibit brucite precipitation (e.g., Bach et al., 2004; Sonzogni et al., 2017), and the absence of brucite in our specimens indicates that the olivine of ultramafic rocks in the Manlay Ophiolite reacted with Si-rich fluids to generate lizardite without brucite (Fig 4a-c).

The serpentinization of orthopyroxene produces bastite textures, which are pseudomorphs of orthopyroxene and easily distinguished by the preservation of the pyroxene cleavage positions (e.g., Deschamps et al., 2013), and we define Stage II of the serpentinization process as the formation of chrysotile through serpentinization of orthopyroxene (see Eq. 2 below; Fig $3 \mathrm{~b}$ and c). Chrysotile occurs mostly as bastite texture, and it is also often present in the mesh cores and networks of mesh textures in the serpentinized ultramafic rocks of the Manlay Ophiolite. Furthermore, regardless as to their texture, all 
the chrysotiles have similar chemical characteristics (e.g., high in $\mathrm{Al}$ and Fe; Fig 3d and e), which indicates that they were generated at the same time. Moreover, the presence of chrysotile in mesh cores suggests that the cores of some olivine grains survived the stage 1 serpentinization process and are now represented by stage 2 chrysotile in the mesh cores (see Eq. 3).

$$
\begin{aligned}
& \mathrm{Mg}_{2} \mathrm{Si}_{2} \mathrm{O}_{6}+4 \mathrm{H}_{2} \mathrm{O}=2 \mathrm{Mg}_{3} \mathrm{Si}_{2} \mathrm{O}_{5}(\mathrm{OH})_{4}+2 \mathrm{SiO}_{2} \\
& \text { Opx Water Chrysotile Silica } \\
& 3 \mathrm{Mg}_{2} \mathrm{SiO}_{4}+4 \mathrm{H}_{2} \mathrm{O}+\mathrm{SiO}_{2}=2 \mathrm{Mg}_{3} \mathrm{Si}_{2} \mathrm{O}_{5}(\mathrm{OH})_{4} \\
& \text { Olivine Water Silica Chrysotile }
\end{aligned}
$$

Coupled reactions such as Eqs 2 and 3, where silica is released during the serpentinization of orthopyroxene and the released silica then reacts with olivine to form serpentine, have been observed in hydrothermal experiments at $250{ }^{\circ} \mathrm{C}$ (Ogasawara et al., 2013).

According to Evans et al. (2013), chrysotile is found mainly as a filling of fractures that crosscut the serpentinite, indicating it is a common process that occurs as the last stage of serpentinization. In the Manlay Ophiolite, mesh and bastite serpentines are cut by chrysotile veins (Fig 3a and e). Therefore, we define Stage III, the last stage of the serpentinization process, as the development of large veins of chrysotile (Figs 3a and 6).

Serpentinization of ultramafic rocks in southern Mongolia and the $\mathrm{CAOB}$

Mongolia is divided into two domains (southern and northern) by the Main Mongolian Lineament (Badarch et al., 2002). In the northern domain, ophiolites of Neoproterozoic (Dunzhugur, Shishged, Dzhida, Agardagh TesChem, Dariv or Bayan-nuur, Khantaishir, Erdene-Uul, and Bayankhongor), Cambrian (Kherlen), and Carboniferous (Adaatsag and Khuhu Davaa) age are exposed. In the southern domain, ophiolites of Cambrian, Carboniferous (Altan-Uul), and Permian (Solonker or Sulinheer) age crop out (Fig 1a). The Cambrian ophiolites in the southern domain are Gobi-

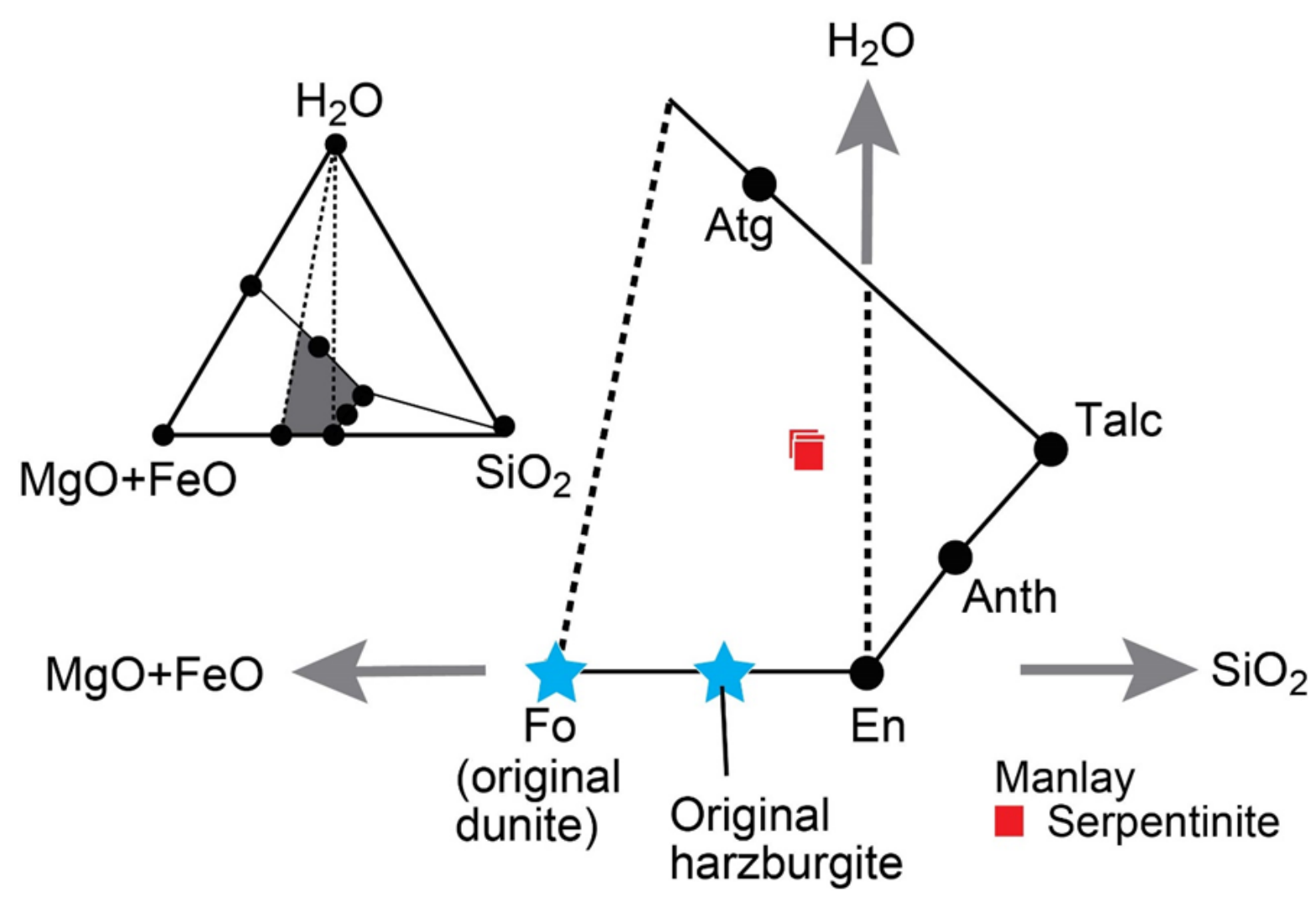

Fig. 5. $(\mathrm{MgO}+\mathrm{FeO})-\mathrm{SiO}_{2}-\mathrm{H}_{2} \mathrm{O}$ ternary diagram based on whole-rock major-element chemistry (wt.\%) and loss on ignition (LOI, wt.\%) values for serpentinites in the Manlay Ophiolite. 
Altai, Gurvan Saykhan-Zoolen (519-511 Ma), Biluutiin Ovoo (525-503 Ma), Namdain Hundy (528-519 Ma), and Manlay (509-482 Ma). The geochemical signatures of crustal rocks from the Gurvan Saykhan-Zoolen, Biluution Ovoo, Namdain Hundy, and Manlay ophiolites suggest supra-subduction zone affinities (Jian et al., 2014; Zhu et al., 2014a, b, 2016). It is clear from the above that southern Mongolia records a long multi-stage oceanic evolution and accretionary history from the early Paleozoic. In the northern domain, Dandar et al. (2019) revealed the following three stages in the multistage serpentinization of ultramafic rocks in the Khantaishir Ophiolite of the Naran Massif: (1)

\section{Harzburgite}

\section{Cr-rich spinel}

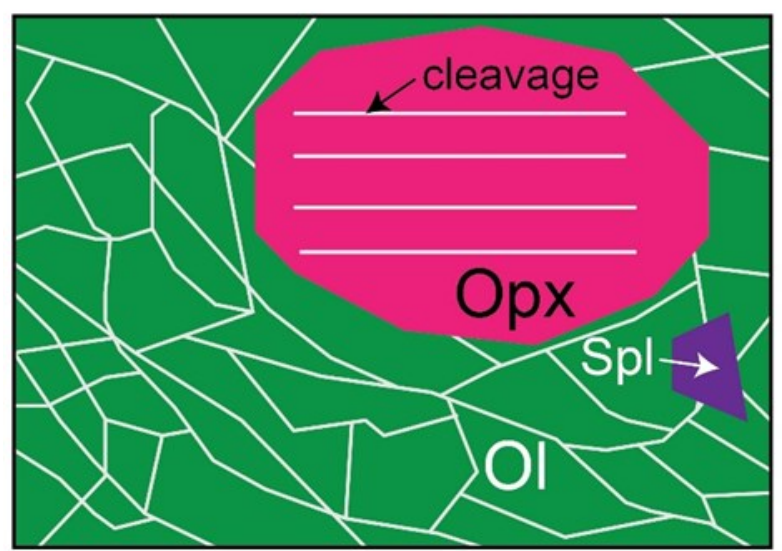

\section{Stage 2}

Chrysotile mesh core, small veins \& bastite

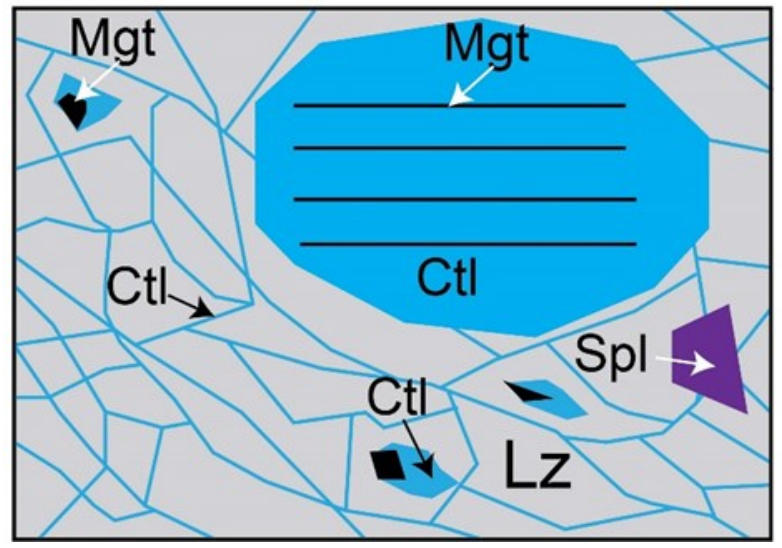

high-temperature serpentinization revealed by antigorite formation during orthopyroxene decomposition to secondary olivine, (2) lizardite + brucite formation after primary and secondary olivine, and (3) development of chrysotile veins that cut across previous textures. In the southern domain, our study of the low-temperature threestage serpentinization of the Manlay Ophiolite provides new insights into the processes involved in this multi-stage serpentinization (lizardite, chrysotile, then chrysotile; Fig 6). Although the multi-stage serpentinization of the Cambrian Manlay Ophiolite may be representative of the history of serpentinization in other Cambrian ophiolites (Gobi-Altai,

\section{Stage 1}

Lizardite mesh core \& rim

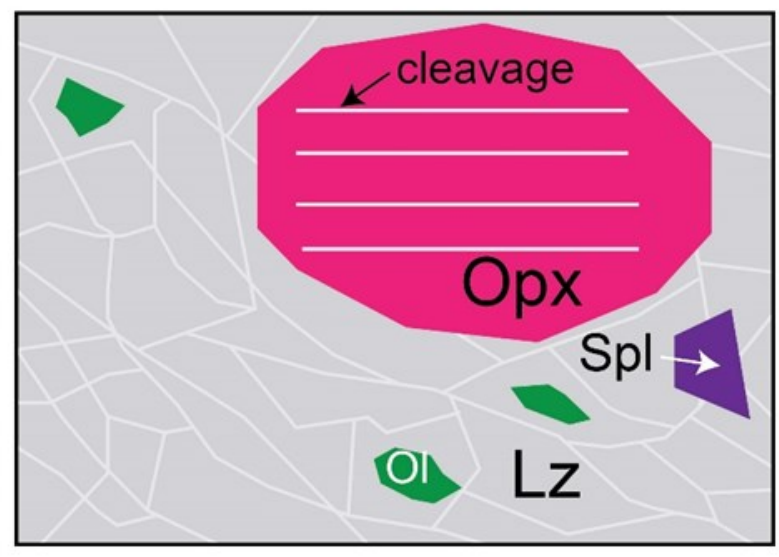

\section{Stage 3}

Chrysotile large vein \& Calcite vein

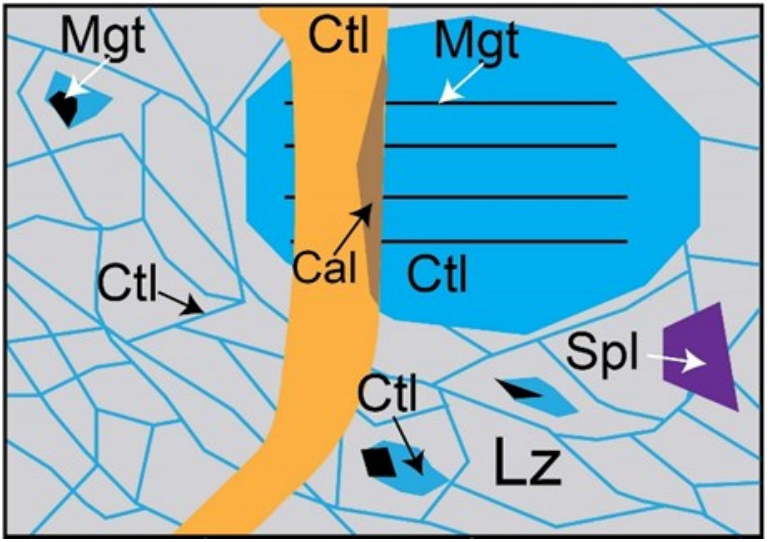

Fig. 6. Microtextural evolution of the three-stage serpentinization of harzburgite in the ultramafic rocks of the Manlay Ophiolite. 
Gurvan Saykhan-Zoolen, Biluutiin Ovoo, and Namdain Hundy) in south Mongolia, further studies of those other ophiolites are still needed if we are to reach a better understanding of the serpentinization and carbonation of ultramafic rocks during the opening of the Paleo-Asian Ocean in southern Mongolia. In addition, the Carboniferous (?) Altan-Uul and Permian Solonker ophiolites may provide key information on the processes of serpentinization and carbonation during the closure of the PaleoAsian Ocean. These studies indicate clearly that the ophiolites of the $\mathrm{CAOB}$ record crucial information on mantle-fluid interactions during both the opening and closure of the Paleo-Asian Ocean.

\section{CONCLUSIONS}

The ultramafic rocks of the Manlay Ophiolite in southern Mongolia, originally composed of olivine and orthopyroxene, have been serpentinized pervasively. Studies of the mineralogy, microstructures, and mineral chemistry of these rocks have revealed many details of the processes of their serpentinization. The compositions of relict $\mathrm{Cr}$-spinels indicate a fore-arc setting for the rocks of the Manlay Ophiolite. Lizardite and chrysotile are the dominant serpentine species, and they demonstrate that the serpentinization took place at low temperatures $\left(<300{ }^{\circ} \mathrm{C}\right)$. The ultramafic rocks of the Manlay Ophiolite were serpentinized by Si-rich fluids, generating serpentines without brucite.

Analyses of the microstructures and mineral chemistry of these rocks reveal three stages of serpentinization: (1) the alteration of most olivine to lizardite; (2) the alteration of orthopyroxene and remnant cores of olivine to chrysotile; and (3) the development of chrysotile veins that cut across previous serpentines.

This multi-stage process of serpentinization provides new insights into the metamorphic history of ophiolite complexes in southern Mongolia and the $\mathrm{CAOB}$, and similar work on the numerous ophiolite complexes in the CAOB should improve our understanding of mantlefluid interactions during the opening and closure of the Paleo-Asian Ocean.

\section{ACKNOWLEDGEMENTS}

We acknowledge O. Gerel, B. Munkhtsengel, B. Batkhishig, and A. Chimedtseren for introducing us to this field of study and providing advice. We thank Burenjargal Ulziiburen, Manzshir Bayarbold, Geri Agroli, and Kazuki Yoshida for their support during field and laboratory work. We are also grateful to Shin-ichi Yamasaki for help with the XRF analysis. This research was supported by JSPS KAKENHI Grants $16 \mathrm{H} 06347,17 \mathrm{H} 02981$, and $18 \mathrm{KK} 0376$ to A.O and JP25000009 to N.T.

\section{REFERENCES}

Auzende, A.L., Daniel, I., Reynard, B., Lemaire, C., Guyot, F. 2004. High-pressure behaviour of serpentine minerals: a Raman spectroscopic study. Physics and Chemistry of Minerals, v. 31(5), p. 269-277. https://doi.org/10.1007/s00269-004-0384-0

Bach, W., Garrido, C.J., Paulick, H., Harvey, J., Rosner, M. 2004. Seawater-peridotite interactions: First insights from ODP Leg 209, MAR 15 N. Geochemistry, Geophysics, Geosystems, 5(9).

https://doi.org/10.1029/2004GC000744

Badarch, G., Cunningham, W. D., Windley, B.F. 2002. A new terrane subdivision for Mongolia: implications for the Phanerozoic crustal growth of Central Asia. Journal of Asian Earth Sciences, v. 21(1), p. 87-110. https://doi.org/10.1016/S1367-9120(02)00017-2

Batkhishig, B., Noriyoshi, T., Greg, B. 2010. Magmatism of the Shuteen Complex and Carboniferous subduction of the Gurvansaikhan terrane, South Mongolia. Journal of Asian Earth Sciences, v. 37(5-6), p. 399-411.

https://doi.org/10.1016/j.jseaes.2009.10.004

Blight, J.H.S., Petterson, M.G., Crowley, Q.G., Cunningham, D. 2010. The Oyut Ulaan volcanic group: stratigraphy, magmatic evolution and timing of Carboniferous arc development in southeast Mongolia. Journal of Geological Society, London, v. 167, p. 491509.

https://doi.org/10.1144/0016-76492009-094

Dandar, O., Okamoto, A., Uno, M., Oyanagi, R., Nagaya, T., Burenjargal, U., Tsuchiya, N. 2019. Formation of secondary olivine after orthopyroxene during hydration of mantle 
wedge: evidence from the Khantaishir Ophiolite, western Mongolia. Contributions to Mineralogy and Petrology, v. 174(11), p. 1-22. https://doi.org/10.1007/s00410-019-1623-1.

Dandar, O., Okamoto, A., Uno, M., Tsuchiya, N. 2021. Redistribution of magnetite during multi-stage serpentinization: Evidence from the Taishir Massif, the Khantaishir Ophiolite, western Mongolia. Journal of Mineralogical and Petrological Sciences, v. 116, p. 176-181. https://doi.org/10.2465/jmps.201130a

Deschamps, F., Godard, M., Guillot, S., Hattori, K. 2013. Geochemistry of subduction zone serpentinites: A review. Lithos, v. 178, p. 96127.

https://doi.org/10.1016/j.lithos.2013.05.019

Dobson, D.P., Meredith, P.G., Boon, S.A. 2002. Simulation of subduction zone seismicity by dehydration of serpentine. Science, v. 298 (5597), p. 1407-1410. https://doi.org/10.1126/science.1075390

Evans, B.W., Hattori, K., Baronnet, A. 2013. Serpentinite: what, why, where?. Elements, v. 9(2), p. 99-106.

https://doi.org/10.2113/gselements.9.2.99

Frost, B.R., Beard, J.S. 2007. On silica activity and serpentinization. Journal of Petrology, v. 48(7), p. 1351-1368. https://doi.org/10.1093/petrology/egm021

Furnes, H., Safonova, I. 2019. Ophiolites of the Central Asian Orogenic Belt: Geochemical and petrological characterization and tectonic settings. Geoscience Frontiers, v. 10(4), p. 1255-1284.

https://doi.org/10.1016/j.gsf.2018.12.007

Guillot, S., Hattori, K. 2013. Serpentinites: Essential roles in geodynamics, arc volcanism, sustainable development, and the origin of life. Elements, v. 9(2), p. 95-98. https://doi.org/10.2113/gselements.9.2.95

Hattori, K H., Guillot, S. 2007. Geochemical character of serpentinites associated with high -to ultrahigh-pressure metamorphic rocks in the Alps, Cuba, and the Himalayas: Recycling of elements in subduction zones. Geochemistry, Geophysics, Geosystems, v. 8 (9).

https://doi.org/10.1029/2007GC001594

Holland, T.J.B., Powell, R.T.J.B. 1998. An internally consistent thermodynamic data set for phases of petrological interest. Journal of
Metamorphic Geology, v. 16(3), p. 309-343. https://doi.org/10.1111/j.1525-1314.1998.00140.x

Jahn, B.M., Windley, B., Natalin, B., Dobretsov, N.L. 2004. Phanerozoic continental growth in Central Asia. Journal of Asian Earth Sciences, v. 23(5), p. 599-603.

https://doi.org/10.1016/S1367-9120(03)00124-X

Jian, P., Kroner, A., Jahn, B., Windley, F. B., Shi, Y., Zhang, W., Zhang, F., Miao, L., Tomurhuu, D., Liu, D. 2014. Zircon dating of Neoproterozoic and Cambrian ophiolites in West Mongolia and implications for the timing of orogenic processes in the central part of the Central Asian Orogenic Belt. Earth -Sciences Reviews, v. 133, p. 62-93. https://doi.org/10.1016/j.earscirev.2014.02.006

Klein, F., Bach, W., Humphris, S.E., Kahl, W. A., Jöns, N., Moskowitz, B., Berquó, T.S. 2014. Magnetite in seafloor serpentinite-Some like it hot. Geology, v. 42(2), p. 135-138. https://doi.org/10.1130/G35068.1

Lafay, R., Deschamps, F., Schwartz, S., Guillot, S., Godard, M., Debret, B., Nicollet, C. 2013. High-pressure serpentinites, a trap-and-release system controlled by metamorphic conditions: Example from the Piedmont zone of the western Alps. Chemical Geology, v. 343, p. 38 -54 .

https://doi.org/10.1016/j.chemgeo.2013.02.008

Lamb, M.A., Badarch, G. 1997. Paleozoic sedimentary basins and volcanic-arc systems of Southern Mongolia: new stratigraphic and sedimentologic constraints. International Geology Review, v. 39(6), p. 542-576. https://doi.org/10.1080/00206819709465288

Lamb, M.A., Cox, D. 1998. New $40 \mathrm{Ar} / 39 \mathrm{Ar}$ age data and implications for porphyry copper deposits of Mongolia. Economic Geology, v. 93(4), p. 524-529. https://doi.org/10.2113/gsecongeo.93.4.524

Martin, W., Baross, J., Kelley, D., Russell, M.J. 2008. Hydrothermal vents and the origin of life. Nature Reviews Microbiology, v. 6(11), p. $805-814$.

https://doi.org/10.1038/nrmicro1991

Moody, J.B. 1976. Serpentinization: a review. Lithos, v. 9(2), p. 125-138. https://doi.org/10.1016/0024-4937(76)90030-X

Ogasawara, Y., Okamoto, A., Hirano, N., Tsuchiya, N. 2013. Coupled reactions and silica diffusion during serpentinization. 
Geochimica et Cosmochimica Acta, v. 199, p. 212-230.

https://doi.org/10.1016/j.gca.2013.06.001

Ohara, Y., Reagan, M. K., Fujikura, K., Watanabe, H., Michibayashi, K., Ishii, T., Kino, M. 2012. A serpentinite-hosted ecosystem in the Southern Mariana Forearc. Proceedings of the National Academy of Sciences, v. 109(8), p. 2831-2835. https://doi.org/10.1073/pnas.1112005109

Oyanagi, R., Okamoto, A., Tsuchiya, N. 2020. Silica controls on hydration kinetics during serpentinization of olivine: Insights from hydrothermal experiments and a reactive transport model. Geochimica et Cosmochimica Acta, v. 270, p. 21-42. https://doi.org/10.1016/j.gca.2019.11.017

Perello, J., Cox, D., Garamjav, D., Sanjdorj, S., Diakov, S., Schissel, D., Munkhbat, T-O., Oyun, G. 2001. Oyu Tolgoi, Mongolia: Siluro -Devonian porphyry $\mathrm{Cu}-\mathrm{Au}-(\mathrm{Mo})$ and highsulfidation $\mathrm{Cu}$ mineralisation with a Cretaceous chalcocite blanket. Economic Geology, v. 96 (6), p. 1407-1428.

https://doi.org/10.2113/gsecongeo.96.6.1407

Pinti D.L. 2011. Serpentinization. In: Gargaud M. et al. (eds) Encyclopedia of Astrobiology. Springer, Berlin, Heidelberg.

https://doi.org/10.1007/978-3-642-11274-4 1430

Power, I.M., Wilson, S.A., Dipple, G.M. 2013. Serpentinite carbonation for $\mathrm{CO} 2$ sequestration. Elements, v. 9(2), p. 115-121. https://doi.org/10.2113/gselements.9.2.115

Schwartz, S., Allemand, P., Guillot, S. 2001. Numerical model of the effect of serpentinites on the exhumation of eclogitic rocks: insights from the Monviso ophiolitic massif (Western Alps). Tectonophysics, v. 342(1-2), p. 193206.

https://doi.org/10.1016/S0040-1951(01)00162-7

Schwartz, S., Guillot, S., Reynard, B., Lafay, R., Debret, B., Nicollet, C., Auzende, A.L. 2013. Pressure-temperature estimates of the lizardite/antigorite transition in high pressure serpentinites. Lithos, v. 178, p. 197-210. https://doi.org/10.1016/j.lithos.2012.11.023

Schwarzenbach, E.M., Caddick, M.J., Beard, J.S., Bodnar, R.J. 2016. Serpentinization, element transfer, and the progressive development of zoning in veins: evidence from a partially serpentinized harzburgite.
Contributions to Mineralogy and Petrology, v. 171(1), p. 1-22.

https://doi.org/10.1007/s00410-015-1219-3

Şengör, A.M.C., Natal'In, B.A., Burtman, V.S. 1993. Evolution of the Altaid tectonic collage and Palaeozoic crustal growth in Eurasia. Nature, v. 364(6435), p. 299-307. https://doi.org/10.1038/364299a0

Sonzogni, Y., Treiman, A.H., Schwenzer, S.P. 2017. Serpentinite with and without brucite: A reaction pathway analysis of a natural serpentinite in the Josephine ophiolite, California. Journal of Mineralogical and Petrological Sciences, v. 112(2), p. 59-76. https://doi.org/10.2465/jmps.160509

Uno, M., Kirby, S. 2019. Evidence for multiple stages of serpentinization from the mantle through the crust in the Redwood City Serpentinite mélange along the San Andreas Fault in California. Lithos, v. 336, p. 276-292. https://doi.org/10.1016/j.lithos.2019.02.005

Tamura, A., Arai, S. 2006. Harzburgite-duniteorthopyroxenite suite as a record of suprasubduction zone setting for the Oman ophiolite mantle. Lithos, v. 90, p. 43-56. https://doi.org/10.1016/j.lithos.2005.12.012

Wang, J., Watanabe, N., Okamoto, A., Nakamura, K., Komai, T. 2019. Pyroxene control of $\mathrm{H} 2$ production and carbon storage during water-peridotite-CO2 hydrothermal reactions. International Journal of Hydrogen Energy, v. 44(49), p. 26835-26847.

https://doi.org/10.1016/j.ijhydene.2019.08.161

Windley, B.F., Alexeiev, D., Xiao, W., Kröner, A., Badarch, G. 2007. Tectonic models for accretion of the Central Asian Orogenic Belt. Journal of the Geological Society, v. 164(1), p. 31-47.

https://doi.org/10.1144/0016-76492006-022

Yamasaki, S.I., Matsunami, H., Takeda, A., Kimura, K., Yamaji, I., Ogawa, Y., Tsuchiya, N. 2011. Simultaneous determination of trace elements in soils and sediments by polarizing energy dispersive X-ray fluorescence spectrometry. Bunseki Kagaku= Journal of Japanese Society for Analytical Chemistry, v. 60(4), p. 315-323.

https://doi.org/10.2116/bunsekikagaku.60.315

Zhu, M., Baatar, M., Miao, L., Anaad, C., Zhang, F., Yang, S., Li, Y. 2014a. Zircon ages and geochemical compositions of the Manlay 
ophiolite and coeval island arc: Implications for the tectonic evolution of South Mongolia. Journal of Asian Earth Sciences, v. 96, p. 108122.

https://doi.org/10.1016/j.jseaes.2014.09.004

Zhu, M., Miao, L., Baatar, M., Zhang, F., Anaad, C., Yang, S., Li, Y. 2014b. Zircon ages and geochemical data of the Biluutiin ovoo ophiolite: implication for the tectonic evolution of South Mongolia. International Geology Review, v. 56(14), p. 1769-1782. https://doi.org/10.1080/00206814.2014.956817
Zhu, M., Baatar, M., Miao, L., Anaad, C., Zhang, F., Yang, S., Li, X. 2016. Early Paleozoic oceanic inliers and reconstruction of accretionary tectonics in the Middle Gobi region, Mongolia: Evidence from SHRIMP zircon U-Pb dating and geochemistry. Journal of Asian Earth Sciences, v. 127, p. 300-313. https://doi.org/10.1016/j.jseaes.2016.06.018 